\title{
都市中小河川における集中豪雨時の洪水流出特性 \\ CHARACTERISTICS OF HEAVY RAINFALL AND FLOOD DISCHARGE IN URBAN SMALL RIVER BASIN
}

\author{
高崎 忠勝 $^{1} \cdot$ 土屋 十完 ${ }^{2}$ \\ Tadakatsu TAKASAKI and Mitsukuni TSUCHIYA \\ ${ }^{1}$ 正会員 東京都土木技術研究所 技術部（广136-0075 東京都江東区新砂一丁目 9-15） \\ ${ }^{2}$ 正会員 工博 前橋工科大学教授 工学部建設工学科（广371-0816 群馬県前橋市上佐鳥町 460-1)
}

\begin{abstract}
Recently, heavy rainfall have frequent occurrence in the Central Tokyo. In this paper, the characteristics of floods in small urban river are explained using observed rainfall and waterlevel data, a using model is concerted, timely. The parameter of this model was decided by using Genetic Algorithms, that have the ability to do on an optimization problem from rainfall and water-level data in 2004. Flooding disasters were occurred in Myoshoji River basin due to heavy rainfall which exceeded $100 \mathrm{~mm} / \mathrm{h}$ on September 4, 2005. A calculated peak discharge is estimated as the design peak discharge against an hourly rainfall of $60 \mathrm{~mm}$. The heavy rainfall appeared in the upstream areas of urban river basin was the cause that enlarged flooding disaster. The flood control plan which was adapted for basin area scale can be expected decrease a flooding disaster.
\end{abstract}

Key Words : urban small river basin, runoff simulation, genetic algorithm, peak discharge, rainfall distribution

\section{1. はじめに}

現在，東京都では現在 1 時間に $50 \mathrm{~mm}$ の降雨に対応で きるよう河川改修をすすめている.しかし，しばしば発 生する集中豪雨においては計画雨量を越える雨量を観測 しており，近年の浸水被害の多くは集中豪雨によるもの となっていることから, 都市中小河川における集中豪雨 対策は大きな課題となっている。

2005 年 9 月 4 日昼過ぎから 5 日明け方にかけて 23 区 西部や多摩北部を中心に大雨となり、杉並区内や三鷹市 内において 1 時間に $100 \mathrm{~mm}$ を超える雨量を観測した. 区 部を流れる妙正寺川では溢水し，流域が位置寸る中野区， 杉並区では合計で 2500 棟以上が浸水した.

到達時間の組合せによる流出モデルは, 都市中小河川 の洪水流出を良好に再現 ${ }^{1)}$ することから、このモデルを 用いて、妙正寺川の洪水流出特性を把握するとともに集 中豪雨時の雨量空間分布について分析した. これらの結 果をもとに, 都市中小河川における集中豪雨への対策に ついて考察した.

\section{2. 対象流域}

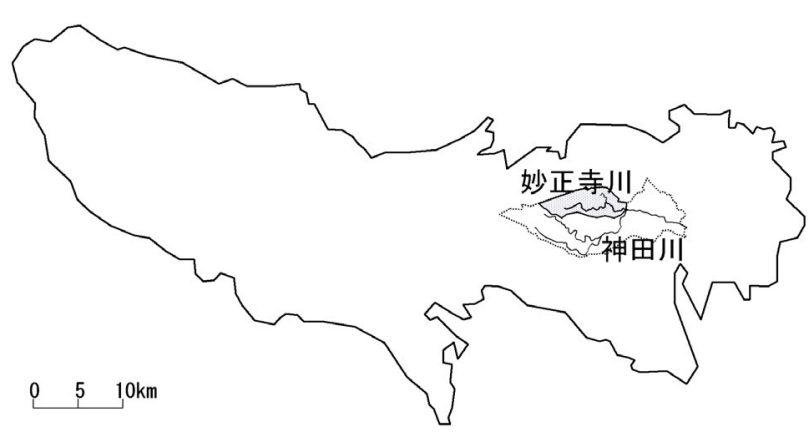

図-1 対象流域

\section{(1) 解析対象}

図-1 に示した妙正寺川は, 流域面積 $21.4 \mathrm{~km}^{2}$, 延長 9. $7 \mathrm{~km}$ の荒川水系の一級河川である. 杉並区清水三丁目 の妙正寺池に源を発し中野区北部を東流して途中江戸田 川を合流させ新宿区に入り, 高田馬場分水路を流下し高 戸橋で神田川に合流する.

河川改修は昭和 50 年度に $30 \mathrm{~mm} / \mathrm{hr}$ 規模の改修が完了 しており, 現在は調節池の整備により $50 \mathrm{~mm} / \mathrm{hr}$ 規模の改 修を進めている. 流域は都市化が進行し流出特性は下水 道の影響を大きく受けたものとなっている2). 


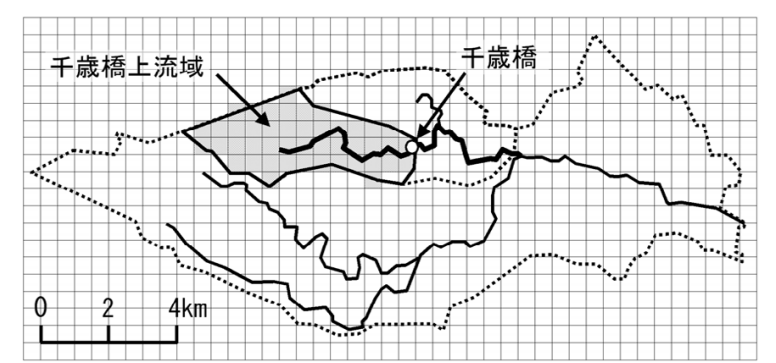

図-2 洪水流出解析地点

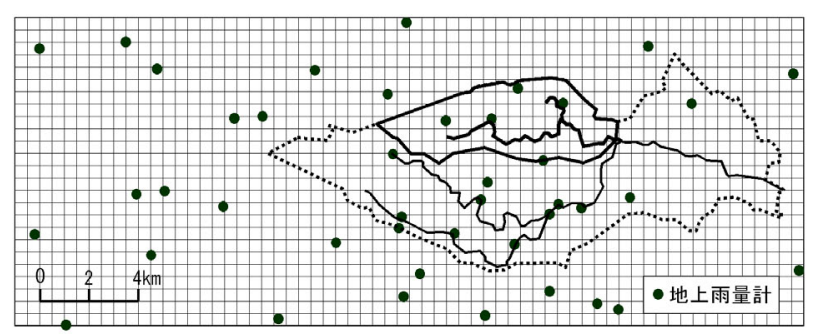

図-3 地上雨量計配置状況

\section{（2）解析地点}

図-2 に洪水流出解析対象とした妙正寺川千歳橋及び その上流域を示した. 千歳橋は上流から $4.8 \mathrm{~km}$ の地点に あり，上流域を $500 \mathrm{~m}$ メッシュ 45 個で構成した. 流域 面積は $11.25 \mathrm{~km}^{2}$ である. 観測流量は流量観測により求 めた水位流量曲線を用いて水位計の観測值から算出した.

\section{（3）流域雨量}

図-3 に地上雨量計の配置状況を示した.

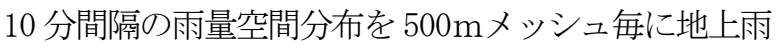
量計の観測值を用いて式(1)〜 (2)により作成した.

$$
\begin{aligned}
& r=\frac{\sum_{j=1}^{n} W j \cdot R j}{\sum_{j=1}^{n} W_{j}} \\
& W j=\frac{1}{L j^{2}} \\
& r: \text { メッシュ雨量 }(\mathrm{mm} / 10 \text { 分 }) \\
& n: \text { メッシュから } 5 \mathrm{~km} \text { 以内に位置する観測所数 } \\
& R j: \text { 観測所 } j \text { の観測值 (mm/10 分) } \\
& W j: \text { 観測所 } j \text { の距離による重み } \\
& L j: \text { メッシュから観測所 } j \text { までの距離 }
\end{aligned}
$$

\section{2. 流出解析}

\section{（1）洪水流出モデル}

都市中小河川の洪水流出現象は河川及び下水道の流下 時間が到達時間を支配する. 河川及び下水道内の平均流 速は流量が大きくなると一定の值に近づくことから，都 市中小河川流域内の任意の地表面における到達時間は流 量の関数となる. 流量と有効雨量の間に線形の関係があ
ると考えると到達時間を式(3)で表すことができる.

$$
\begin{aligned}
& T i=T i m i n+a \cdot R E_{i}^{-b} \\
& T i \text { : 地表面 } i \text { における到達時間 } \\
& T i \min : \text { 地表面 } i \text { における最小到達時間 } \\
& R E i \text { : 地表面 } i \text { における有効雨量 } \\
& a, b: \text { 有効雨量による到達時間変化を表す係数 }
\end{aligned}
$$

雨量の損失を式(4), 地表面が有する到達時間の組合 せによる流出量を式(5)で表した.

$$
\begin{aligned}
& R E_{i}=R_{i}-R L_{i} \\
& R E i \text { : 地表面 } i \text { における有効雨量 } \\
& R i \text { : 地表面 } i \text { における降水量 } \\
& R L i \text { : 地表面 } i \text { における損失雨量 } \\
& \boldsymbol{Q}(t)=\sum_{i=1}^{n} K_{i} \cdot R E_{i\left(t-T_{i}\right)} \cdot A i+Q o(t) \\
& Q(t) \text { : 時刻 } t \text { における流域最下流地点の流量 } \\
& n \text { : 流域を構成する地表面数 } \\
& R E i(t) \text { : 地表面 } i \text { における時刻 } t \text { の有効雨量 } \\
& T i \text { : 地表面 } i \text { に降った雨が流域最下流地点に到達寸るのに } \\
& \text { 要する時間 (到達時間) } \\
& K i \text { : 到達時間 } T i \text { が代表する比率（到達時間係数） } \\
& A i \text { : 地表面 } i \text { が有する面積 } \\
& Q 0(t) \text { : 時刻 } t \text { における流域最下流地点の基底流量 }
\end{aligned}
$$

式(5)の到達時間係数 $K i$ は，地表面 $i$ における流出に 寄与寸る面積の比率を表す. 基底流量 $Q 0(t)$ は，水平分 離として取り扱い降雨直前の流量を入力した.

式(3)の最小到達時間 Timin, 係数 $a, b$, 式(4)の損失 雨量 $R L i$, 式(5)の到達時間係数 $K i$ がパラメータである. 1 地表面を 1 メッシュであらわすと, メッシュ 45 個で 構成した千歳橋流域のパラメータ数は 225 となる.

観測流量と計算流量をできるだけ等しくするパラメー タの組合せを遺伝的アルゴリズムにより求める. 遺伝的 アルゴリズムは，生物進化をモデル化したものであり， 最適化問題に優れた能力 ${ }^{3), 4}$ を有する.

遺伝的アルゴリズムの設定は個体群を 100 とし, 式 (6)の関数により個体を評価した.

$$
\begin{aligned}
& f g=\sum_{t=t_{1}}^{t_{2}} \frac{(Q(t)-q(t))^{2} \cdot\left(q(t)-q_{\min }\right)}{q_{\max }-q_{\min }+0.1} \\
& f_{g}: \text { 個体 } g \text { の評価值 } \\
& q(t) \text { : 時刻 } t \text { における水位観測地点の流量 } \\
& Q(t) \text { : 時刻 } t \text { における水位観測地点の計算流量 } \\
& t 1 \text { : 洪水流出開始時刻 } \\
& t 2 \text { : 洪水流出終了時刻 } \\
& q_{\text {max }}: \text { 洪水流出期間中の観測最大流量 } \\
& q_{m i n} ： \text { 洪水流出期間中の観測最小流量 }
\end{aligned}
$$




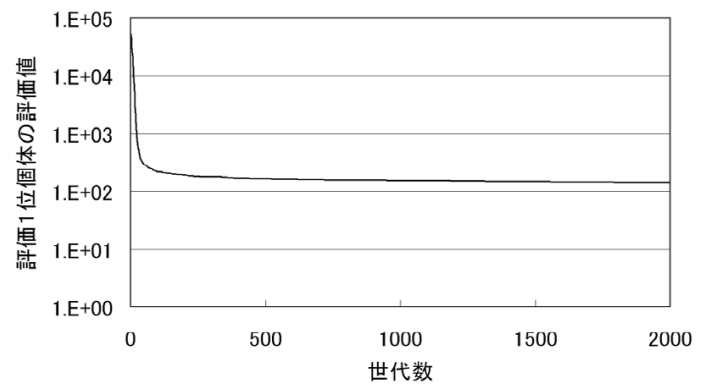

図-4 パラメータ最適化状況（5 降雨）

流量が大きいときの評価の重みを大きくしており， qmin は増水開始前の流量である. パラメータは 2000 世 代における評価 1 位個体が有する情報を用いた.

\section{（2）流域の洪水流出特性}

2004 年の 5 降雨時の雨量, 水位データを用いてパラ メータの最適化をおこなった，計算においては空間単位 を $500 \mathrm{~m}$ ，時間単位を 10 分間とした. 遺伝的アルゴリ ズムによるパラメータの最適化状況について各世代の評 価 1 位個体の評価值を図-4 に示した。 個体の評価は対 象降雨全期間に対しての評価である. 200 世代で概ね最 適化が終了していることがわかる.

流量の再現結果を図-5 に示した. 図中の計算流量 1 は 5 降雨全てのデータを用いたパラメータであり, 計算 流量 2 は再現計算の降雨を除いた 4 降雨のデータを用い たパラメータである. 再現計算の降雨を除いた 4 降雨の データを用いたパラメータによる再現計算が 5 降雨時の 流出ハイドロを概ね再現し，5 降雨のデータを用いたパ ラメータによる再現計算では 1 種類のパラメータの組合 せで 5 降雨時の流出八イドロを良好に示すことができた. よって, 求めたパラメータの組合せは流域流出特性を表 していると判断することができる.

流出量が大きくなると地表が有する到達時間は最小到 達時間に近づくことから, 豪雨時の流出特性は最小到達 時間を組合せたものとなる. 式(7) (8)による到達率は降 った雨が流域下流地点に到達寸る地表面積に対寸る設定 時間内の到達時間を有する地表面積の割合であり，流域 の流出特性を表す.

$$
K(T)=\frac{\sum_{i=1}^{n} K i^{\prime}(T)}{\sum_{i=1}^{n} K i}
$$

$K i^{\prime}(T)=K i \quad(T i \leqq T$ のとき $)$

$K i^{\prime}(T)=0 \quad(T i>T$ のとき $)$

$K(T)$ : 到達時間 $T$ における到達率

$T$ : 到達時間

$T i$ : 流域を構成する $i$ 番目のメッシュに降った雨が流域 最下流地点に到達するのに要する時間（到達時間）

$K i$ : 到達時間 $T i$ が代表する比率（到達時間係数）
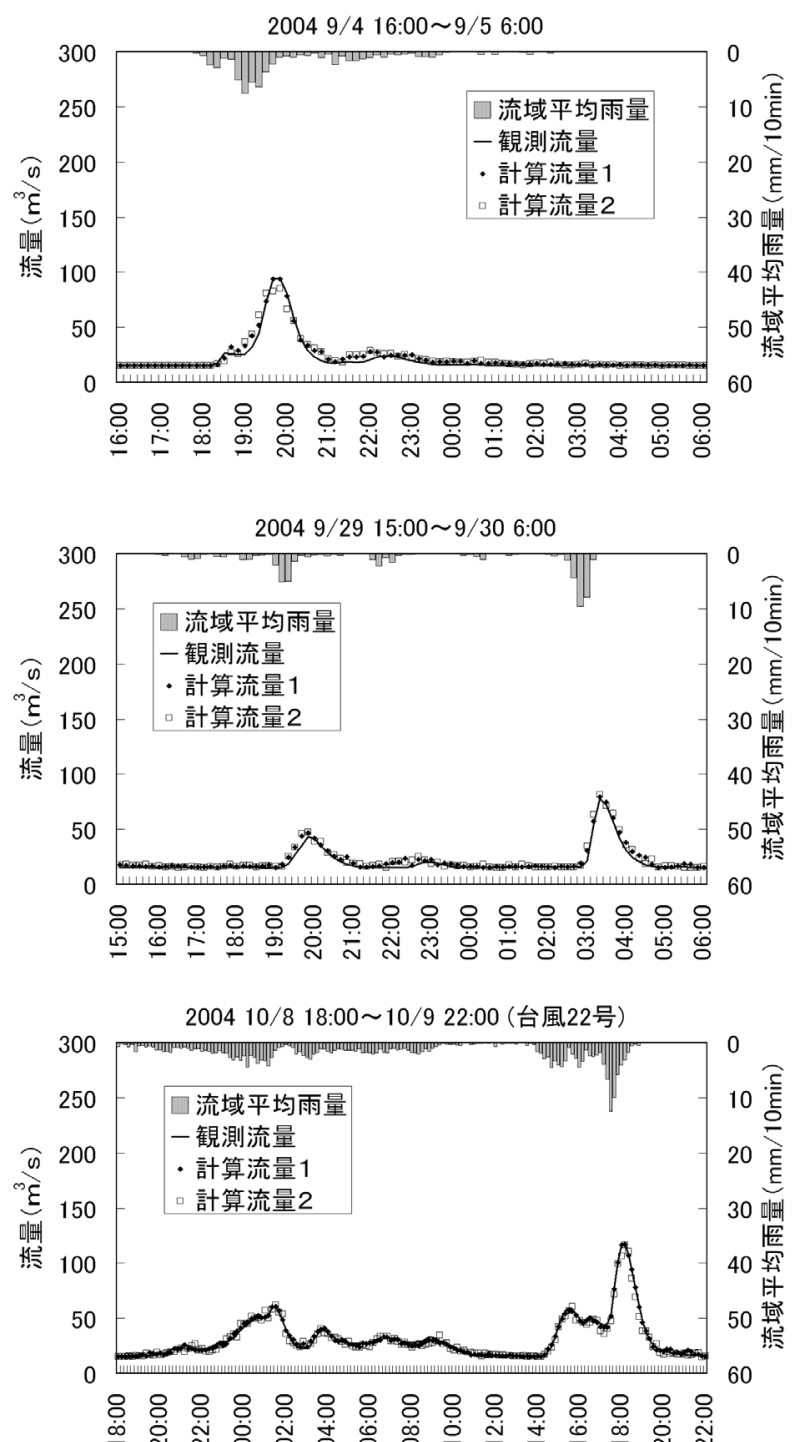

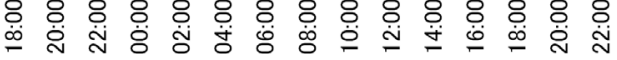
2004 10/20 2:00 10/21 2:00 (台風23号)

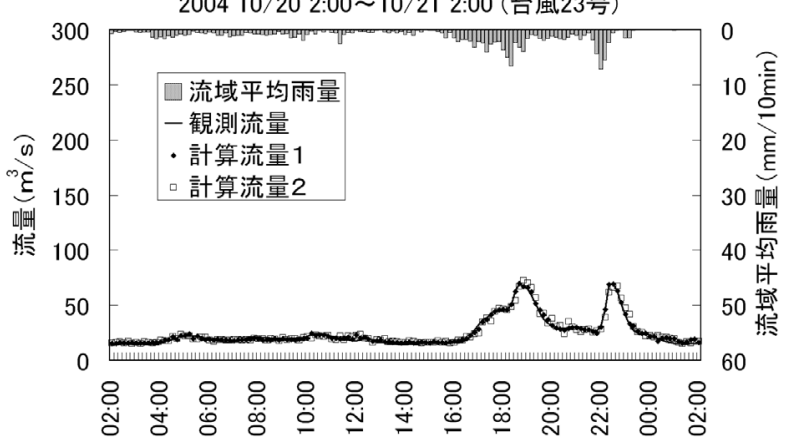

2004 10/30 20:00 10/31 12:00

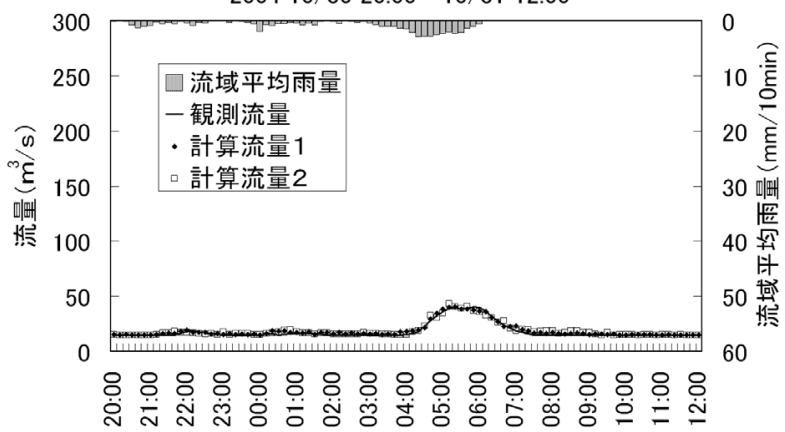

図-5 2004 年洪水再現計算 


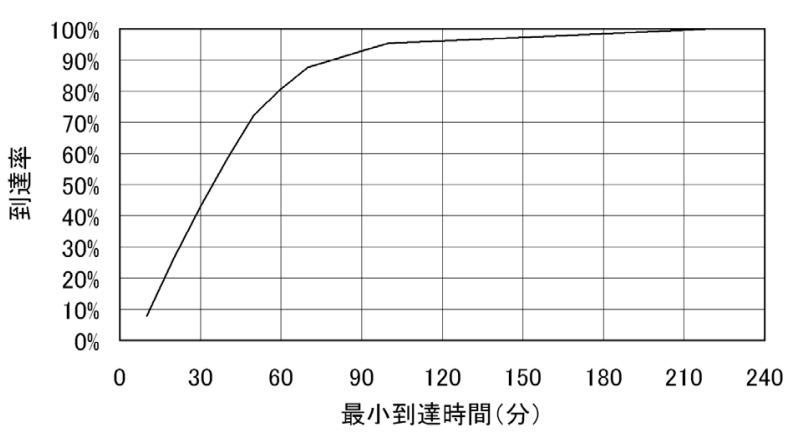

図-6 流出特性

図-6に 2004 年降雨から求めたパラメータによる最小 到達時間と到達率の関係を示す. 最小到達時間 60 分に おける到達率 $81 \%$ は, 降った雨が流域下流地点に到達 する地表面積の $81 \%$ \% 60 分以内の到達時間を有してい ることを示す.

最小到達時間 90 分における到達率は $93 \%$ であり，豪 雨時に千歳橋上流域に降った雨は概ね 90 分以内に千歳 橋に流出することを示している.

\section{(3) 現況の流下能力}

図-7に 2005 年 9 月 4 日豪雨時の流量変化を示した. 21 時 50 分から 24 時 00 分までは溢水のため流量を正 確に観測できていない. 流量変化状況から現況河道の流 下能力は $137 \mathrm{~m}^{3} / \mathrm{s}$ であると判断した.

2004 年降雨から求めたパラメータを用いて規模の異 なる計画雨量に対する流量を計算した. 入力した計画雨 量の降雨強度曲線を図-8, 流量変化を図-9 に示した. 計画雨量 $50 \mathrm{~mm} / \mathrm{hr}$ は現在, 東京都が河川改修の際に使用 しているものである.

計画雨量 $30 \mathrm{~mm} / \mathrm{hr}$ 時の最大流量は $112 \mathrm{~m}^{3} / \mathrm{s}$, 計画雨 量 $40 \mathrm{~mm} / \mathrm{hr}$ 時の最大流量は $147 \mathrm{~m}^{3} / \mathrm{s}$, 計画雨量 $50 \mathrm{~mm} / \mathrm{hr}$ 時の最大流量は $180 \mathrm{~m}^{3} / \mathrm{s}$, 計画雨量 $60 \mathrm{~mm} / \mathrm{hr}$ 時の最大流量は $217 \mathrm{~m}^{3} / \mathrm{s}$ であり, 現況河道の流下能力 は計画雨量 30〜 40mm $/ \mathrm{hr}$ に相当したものとなっている.

\section{（4） 2005 年 9 月 4 日降雨時の流量}

2004 年降雨から求めたパラメータを用いて 2005 年 9 月 4 日降雨時の流量を計算した結果を図-10に示した.

計算流量は 9 月 4 日 21 時 40 分までの流量増加及び 9 月 5 日 1 時 00 分以降の流量を良好に再現している.ま た, 観測流量は計算流量より流量低下が遅れているが, これは溢水の影響であると考える。

河川が溢水していなければ生じたと想定される最大流 量は $206 \mathrm{~m}^{3} / \mathrm{s}$ であり, 現況の流下能力より $69 \mathrm{~m}^{3} / \mathrm{s}$ 大 きな流量である. また, 現況流下能力を超えた溢水流量 は合計で 39 万 $\mathrm{m}^{3} / \mathrm{s}$ である.

$206 \mathrm{~m}^{3} / \mathrm{s}$ の流量は計画雨量 $60 \mathrm{~mm} / \mathrm{hr}$ に相当する流量 であり, 現在進めている計画雨量 $50 \mathrm{~mm} / \mathrm{hr}$ の河川改修が

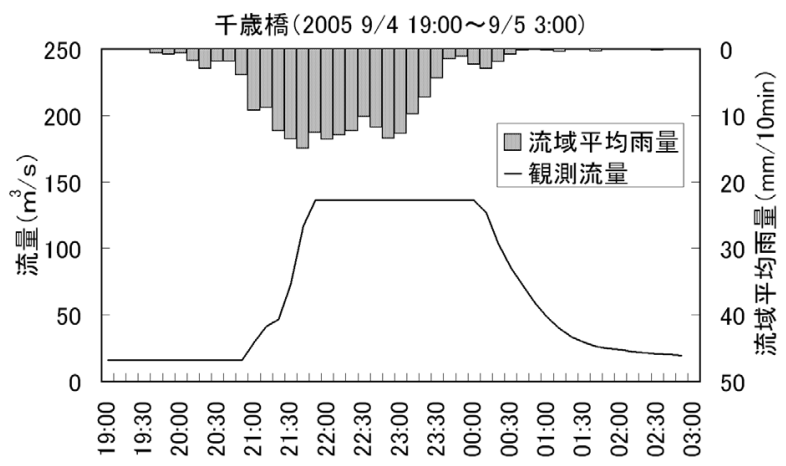

図-7 2005 年 9 月 4 日降雨時の観測流量

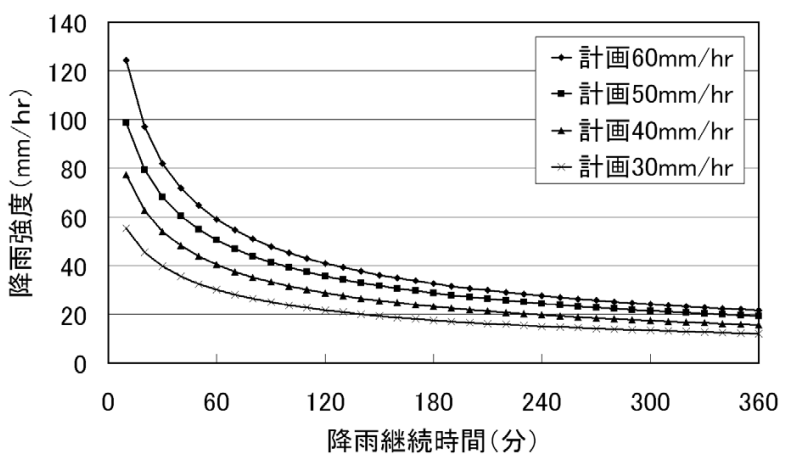

図-8 降雨強度曲線（計画雨量）

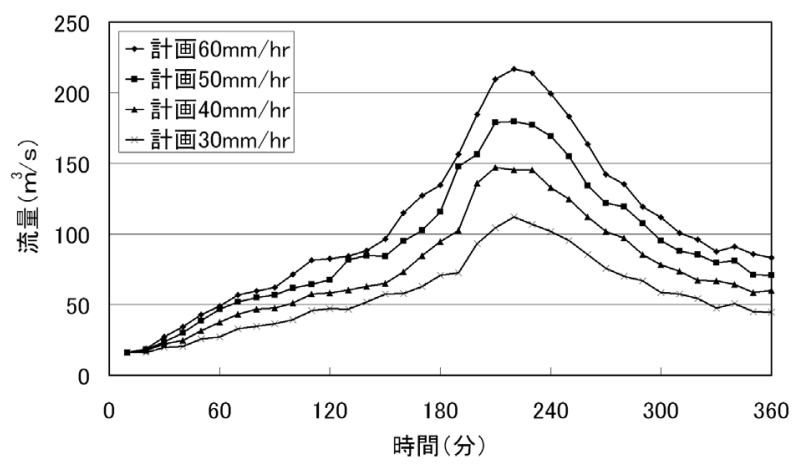

図-9 計画雨量時の流量

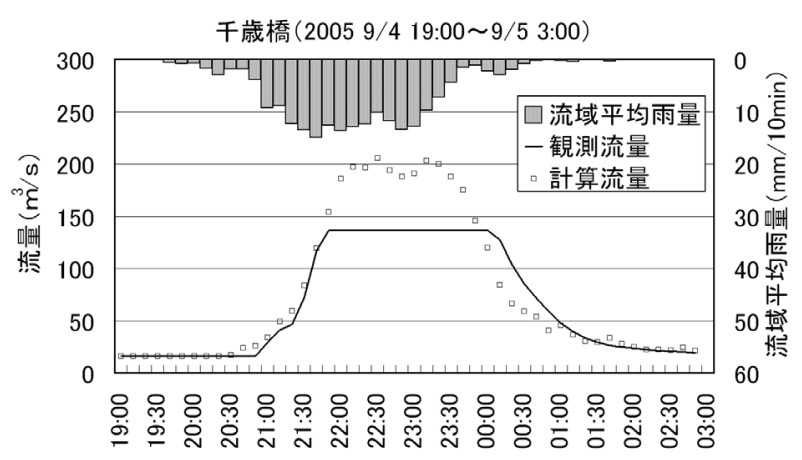

図-10 2005 年 9 月 4 日降雨時の計算流量

終了していても河川の溢水汇濫は生じたと想定される. 


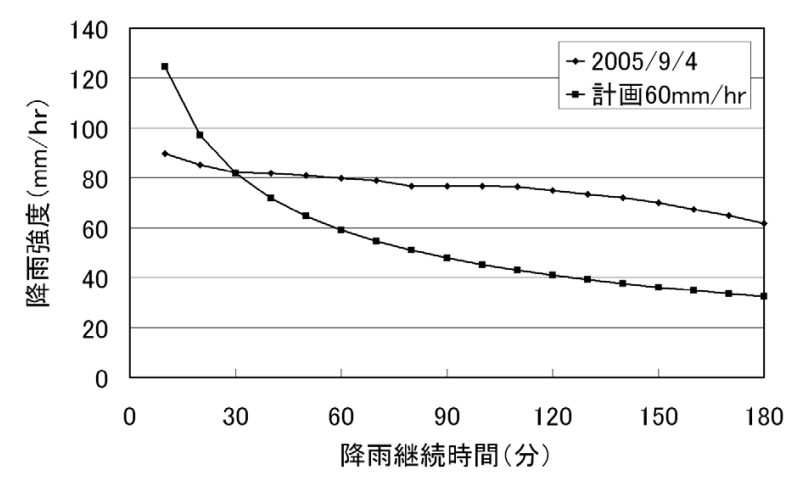

図-11 2005 年 9 月 4 日降雨時の降雨強度曲線
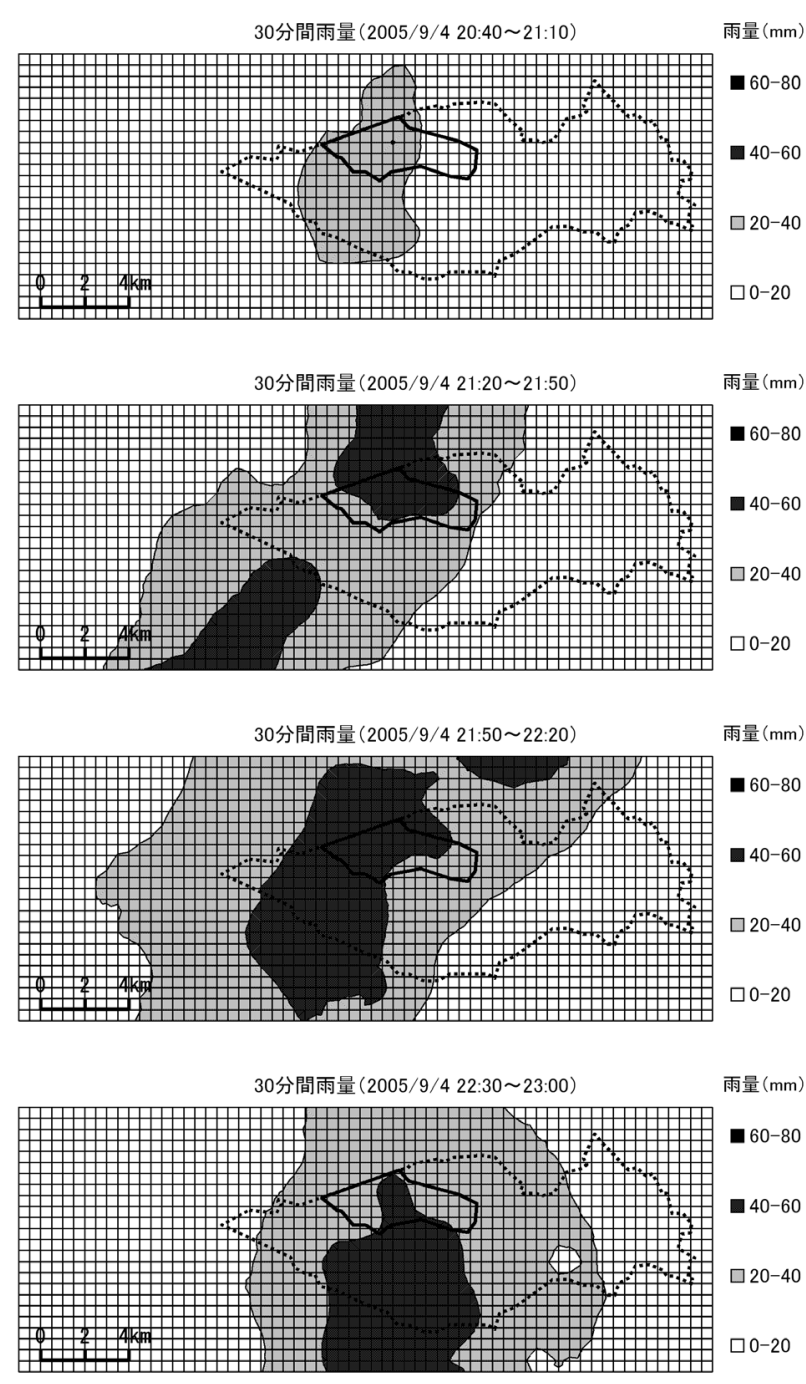

図-12 2005 年 9 月 4 日降雨時の 30 分間雨量空間分布

\section{3. 集中豪雨時の雨量空間分布}

\section{(1) 2005 年 9 月 4 日の 30 分間雨量空間分布}

図-11 に 2005 年 9 月 4 日降雨における千歳橋上流域 平均雨量の降雨強度曲線を示した. 最大流量が同規模で あった計画雨量 $60 \mathrm{~mm} / \mathrm{hr}$ と 2005 年 9 月 4 日降雨の降雨
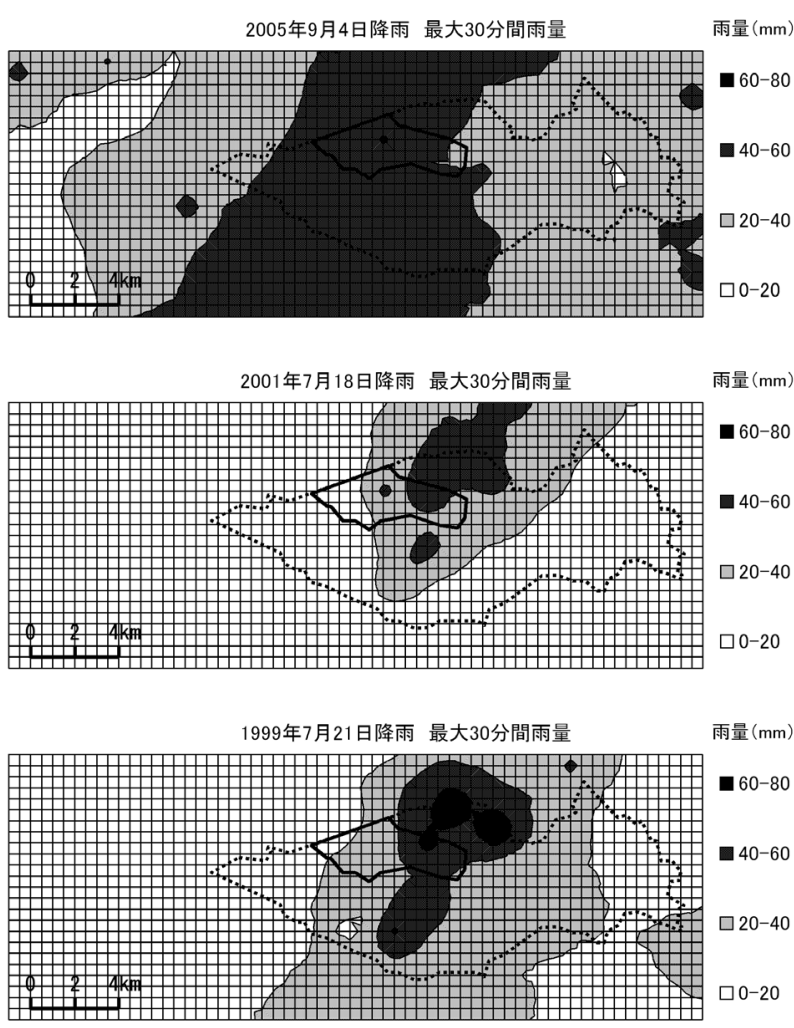

図-13 集中豪雨時の最大 30 分間雨量空間分布

強度を比較すると, 継続時間 30 分以下では 2005 年 9 月 4 日降雨の降雨強度が小さく, 継続時間 30 分以上では 降雨強度が大きいことがわかる． $60 \mathrm{~mm} / \mathrm{hr} \sim 80 \mathrm{~mm} / \mathrm{hr}$ の 強い雨が長時間続いたことが特徽である.

図-12 に 20 時 40 分 21 時 10 分, 21 時 20 分 21 時 50 分, 21 時 50 分 21 時 20 分, 22 時 30 分 23 時 00 分の妙正寺川流域周辺における雨量空間分布を示した.

4 つの 30 分間雨量空間分布に見られる強雨域はそれ ぞれ異なるものであり, 強い雨が長時間続いた原因は異 なる強雨域が連続して流域内を通過したことである.

千歳橋上流域に降った雨は, 豪雨時には概敉 90 分以 内に流出寸る特性を有しているが，2005 年 9 月 4 日降 雨では 90 分間に 3 つの強雨域が流域上を通過しており, 流量は 3 つ強雨域の影響を受けたものとなっている.

\section{（2）過去の集中豪雨時 30 分間雨量空間分布との比較}

次に, 2005 年 9 月 4 日降雨, 2001 年 7 月 18 日降雨, 1999 年 7 月 21 日降雨の最大 30 分間雨量の空間分布を 図-13に示した.

2001 年 7 月 18 日降雨は妙正寺川流域で 122 棟の浸水 被害のあった集中豪雨であり，鷺ノ宮観測所で 1 時間に 92mm の雨量を観測した. 1999 年 7 月 21 日降雨は妙正寺 川流域で 450 棟の浸水被害のあった集中豪雨であり，江 古田観測所で 1 時間に $128 \mathrm{~mm}$ の雨量を観測した.

30 分間雨量 $40 \mathrm{~mm}$ 以上の範囲は, 2001 年 7 月 18 日降 雨と 1999 年 7 月 21 日降雨は楕円形状に分布しているの 
千歳橋(2005 9/4 19:00 9/5 3:00)

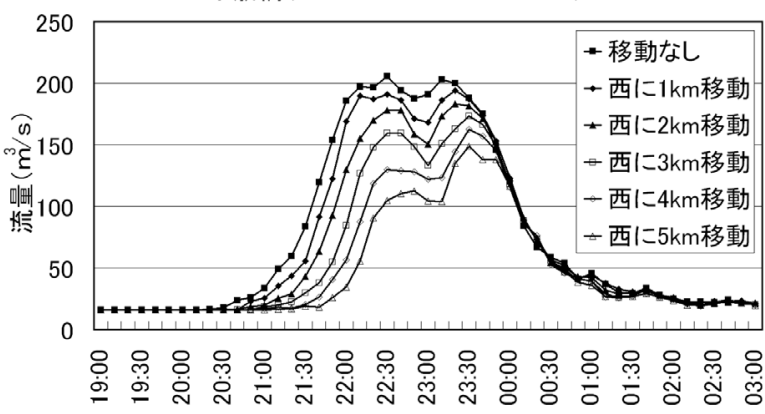

図-14＼cjkstart雨量空間分布移動時の流量

に対して，2005 年 9 月 4 日降雨は南北方向に帯状に分 布し，他の集中豪雨と比べて広範囲であり，神田川上流 域ほぼ全域を含んだものとものとなっている.

1999 年 7 月 21 日降雨における 30 分間雨量 $20 \mathrm{~mm}$ 以上 の範囲は 2005 年 9 月 4 日降雨の 30 分間雨量 $40 \mathrm{~mm}$ 以上 の範囲を東に移動させた分布となっている.

2001 年 7 月 18 日降雨においても 1999 年 7 月 21 日降 雨と同じ位置に南北方向に帯状の降雨域が分布している. 神田川流域周辺で発生する集中豪雨は，南北方向帯状 の範囲に強雨域が形成されやすいことを確認した。

2005 年 9 月 4 日降雨は強雨域が連続して形成されか つ同じ地域を通過したことが過去にこの流域で発生した 集中豪雨との違いであり，また強雨域が通過した地域が 流域面積の小さい中小河川上流域であったことが浸水被 害を大きなものとした.

\section{（3）流出予測における集中豪雨時の雨量空間分布の特徵}

過去の集中豪雨においても，2005 年 9 月 4 日降雨と 同じ地域に強雨域を形成しやすい傾向を確認しており， 今後もこの地域に強雨域が通過する集中豪雨が起こるも のと考えられることから流域面積即ち空間スケールを考 慮した計画雨量設定が必要であると考える.

浸水予測情報を早期に発信することで，浸水被害の軽 減を期待できるが，そのためには精度の高い予測情報を 発信する必要がある. 到達時間の組合せによる洪水流出 モデルは, 2004 年降雨から求めたパラメータで 2005 年 9 月 4 日降雨時の流量変化を増水開始から溢水時まで良 好に再現しており, 都市中小河川の洪水流出における異 なる降雨特性の降雨時の流量変化を 1 種類のパラメータ で良好に再現できる. また, 洪水流出が極めて短時間で ある都市中小河川では予測時の降雨からの流出量が予測 時流量のほとんどを占めることから, 今後の水位予測に おける課題の中心は降雨予測精度の向上である.

図-14に2005 年 9 月 4 日降雨の雨量空間分布を西側 に 1〜 $5 \mathrm{~km}$ 移動させた時の流量を示した. 雨量空間分布 を西に $1 \mathrm{~km}$ 移動する毎に最大流量は約 $10 \mathrm{~m}^{3} / \mathrm{s}$ 減少し, $5 \mathrm{~km}$ 移動した時の最大流量は $149 \mathrm{~m}^{3} / \mathrm{s}$ であり移動しな
い時の $72 \%$ となる. 集中豪雨時には強雨域の空間分布 を正確に把握することが流出量の算定において重要であ る.

集中豪雨時の降雨予測では強雨域の位置がずれて予測 される事例 ${ }^{5)}$ が報告されており，このような場合の水位 予測精度は低いものとなる。

この対策として，予測における強雨域の位置がずれる ことを想定して降雨分布を移動させて複数の計算をおこ なうことで，溢水の危険性を把握する手法が有効だと考 える.

\section{4. まとめ}

2005 年 9 月 4 日降雨は, 流域面積の小さい中小河川 上流域に強雨域が短時間に連続して通過し，流域全域に 強い雨が長時間継続した点が特徵である.

妙正寺川千歳橋付近では上流域に降った雨が概ね 90 分以内に千歳橋に到達する洪水流出特性を有しているが 90 分間に 30 分間雨量 $40 \mathrm{~mm}$ 以上の強雨域が 3 つ通過し たことが洪水流量を極めて大きなものとした．河川が溢 水しなかった場合, 千歳橋付近に $206 \mathrm{~m}^{3} / \mathrm{s}$ の最大流量 が発生し, 河川溢水させないためには計画雨量 $60 \mathrm{~mm} / \mathrm{hr}$ 規模の河川改修が必要となる.

2005 年 9 月 4 日降雨の強雨域は都市中小河川上流域 に位置し，過去の集中豪雨においても同じ地域が強雨域 となる傾向が見られた。

都市中小河川上流域の浸水被害軽減に向けては，流域 面積スケールに応じた計画雨量の設定による集中豪雨へ の対応が必要だと考える. また，ソフト対策である水位 予測においては降雨予測精度の向上が課題である.

\section{参考文献}

1) 高崎忠勝，土屋十图，増田信也 : 都市中小河川における洪水 流出特性の解析手法, 第 60 回年次学術講演概要集, 2-053, pp. 105-106, 2005.

2) 和泉清, 吉川秀夫 : 下水道整備が洪水流出現象に及ぼす影響, 土木学会論文集 No. 399/II-10, pp. 113-120， 1988.

3) 高崎忠勝，土屋十图，増田信也：遺伝的アルゴリズムを用い た都市中小河川の水位予測, 水工学論文集, 第 49 巻, pp. 451-456, 2002.

4) 田中丸治哉 : 遺伝的アルゴリズムによるタンクモデル定数の 同定，京都大学防災研究所年報第 36 号 B-2, pp. 231-239, 1993.

5) 田中創 : 総合数值予測システム SYNFOS（シンフォス）の H16 年豪雨事例人の適用, 水文・水資源学会 2005 年研究発表要 旨集，pp. 20-21，2005.

(2005. 9.30 受付) 